\title{
Accounting Treatment of Biological Assets in Plantation Industry on Wetlands (Case Study in Plantation Company Entities in South Kalimantan)
}

\author{
Chairina $^{1}$, Sarwani $^{1}$ \\ ${ }^{1)}$ Faculty of Economics and Business, Lambung Mangkurat University, Indonesia
}

\begin{abstract}
The purpose of this study is to determine the Accounting treatment of biological assets based on IAS 41 Agriculture. DSAK-IAI in the process of convergence of PSAK with IFRS states that one of the standards that is still being project remaining work since 2010 is IAS 41. IAS 41 is adopted into PSAK No.69 Agriculture as the Accounting standard that regulates special biological assets that will be effectively applicable on 1 January 2018. The results of this study are expected to provide the description of Accounting treatment based on IAS 41 in more detailed and clear in terms of recognition and presentation and disclosure of biological assets. However, in terms of measurement, IAS 41 will be more difficult to implement because the market price for the plantation industry has not been able to be a benchmark of fair value.This research was a qualitative descriptive research by giving a description of the Accounting treatment of biological assets engaged in oil palm plantation. Data collection techniques used questionnaires sent to the company with 10 (ten) samples of oil palm companies representing Banjarmasin City, Banjarbaru City, Banjar Regency, Tapin Regency and Tanah Laut regency. The data were analyzed by using descriptive analysis and index calculation of implementation conformity to the standard. The results showed that the companies have applied the Accounting treatment of biological assets on the average of $90.8 \%$ based on research indicators. In terms of classification the companies have classified $100 \%$ of its biological assets well. Recognition, measurement and assessment of biological assets, the companies applied research indicators in the range of $84 \%-97 \%$, this condition was caused more because the basis of valuation with the fair value of biological assets was not readily available in the active market thus affecting the recognition, measurement and valuation of those assets. While Presentation and Disclosure of Biological Assets in the financial statements, the companies applied $77.5 \%-96 \%$ of the existing disclosure indicators.
\end{abstract}

Keywords: Agriculture, Biological Assets, IAS 41, PSAK No. 69

\section{INTRODUCTION}

Agriculture

company

especially

plantation in its activity has different assets with the assets owned by the company in other fields. In an article written by Sari and Martini (2011) about the Historical Cost vs. Fair Value Accounting on Recognition and Valuation Crops, stated that the plantation industry has special characteristics that distinguish it from other industrial sectors, as demonstrated by the activities of management and biological transformation on plants to produce products that will be consumed or processed further. The

Correspondence Author Charina, Faculty of Economics and Business, LambungMangkurat University, Jl. Hasan Basry, Banjarmasin, Indonesia. Email:

chairina_adnan@yahoo.co.id biological transformation needed a measurement which can show the value of the assets in the agricultural companies fairly in accordance with their contributions in generating economical benefits flow to the company.

In 2000 the International Accounting Standards Committee (IASC) has published International Accounting Standard 41 (IAS 41) on Agriculture which regulates the Accounting treatment during the period of growth, degeneration, production, and procreation, and for the initial measurement of agricultural product at the point of harvest. IAS 41 affects valuation entity of plantation biological assets greatly because based on IAS 41 the biological assets valuation which undergoes the biological transformation is distinguished. The emergence 
of IAS 41 led to the interest of some researchers to conduct researches related to the Accounting treatment of biological assets for the agricultural industry. The research of Ridwan (2011) and Safitri (2012) stated that the measurement of biological assets in the form of plantation crops based on the acquisition price as PSAK 14 and 16 , is deemed incapable of providing relevant information to users of financial statements, since the value has not been able to show information about the true value owned by the biological assets, as IAS 41. In its application, the biological assets can be measured using historical cost and fair value. Historical cost is based on initial acquisition price of the asset. Historical cost method is considered less able to convey reasonable information related to current asset value. On the contrary, the method of fair value allows for each entity to revaluate its biological assets at each period. This method arises because the idea that biological assets are growing and can experience the value change every time, commonly known as biological transformation. IAS 41 was adopted into PSAK 69 Agriculture as an Accounting standard that regulates special biological assets which will become effective on 1 January 2018.

Plantation industry was selected to be analyzed its biological assets Accounting treatment to see the variation in its biological assets Accounting reporting. South Kalimantan is a region with a complex geographic features and dominated by wetlands and has been developing and utilizing natural resources, for example in agriculture, plantation, fishery, and others as the mainstays in its construction and economic development. One of the growing plantation commodities in South Kalimantan is palm oil. The commodities are very suitable to grow in South Kalimantan region because it has the characteristics of wetlands so it is fertile to be planted by plantation commodities. The development of wetlands is to improve the welfare of the community. Empowering communities in the wetlands through the development of plantation commodities is one way to improve the welfare of people in wetlands areas with its natural resources and human potential, also affects agricultural commodities which must have a value if developed properly. It is very important how the Accounting treatment of biological assets derived from agricultural activities.

Biological assets are entity assets of animals and/or plant entities (IAS 41). According to the characteristics of the asset, the biological assets are also the result of the economic transactions of entities in the past, are controlled entirely by the entity, and also expected to provide benefits to the entity in the future. The special characteristic attached to the biological asset lies in the process of transformation or biological change of this asset until it is subsequently consumed or managed by the entity.

In IAS 41, an entity may recognize biological assets if (a) the company controls the asset as a result of past transactions; (b) allows obtainingeconomic benefits in the future that will flow into the company; and (c) have a fair value or cost of the asset which can be measured reliably.

The biological assets in the financial statements may be recognized as either current assets or long term assets in accordance with the period of biological transformation of the biological assets concerned. Measurement of biological assets is adjusted in IAS 41 . Biological assets are measured at fair value. The biological assets shall be measured at initial recognition and at the subsequent reporting date at fair value less the estimation cost of sales, unless the fair value can not be measured reliably. Biological assets information should be disclosed in the Notes of Financial Statements 
of the entity concerned with gains or losses arising from changes in fair value during that period; a description of each group of biological assets, methods and significant assumptions applied in determining the fair value of each group of agricultural product at the point of harvest and each group of biological assets; and the fair value less the cost of sales of agricultural products which are harvested in that period.

This research aims to determine accounting treatment for biological assets on plantation industries based on Financial Accounting Standards and to determine the implementation of Accounting Treatment of Biological Assets on plantation industries in South Kalimantan wetlands, while the benefit of this research is about the activities of agriculture related to the Accounting treatment which classified as long term assets in the financial statements of plantation companies. In fact, the plantation sector has become a source of foreign exchange for non-oil sector for Indonesia with palm oil as its mainstay. This research can give an idea to the company regarding the fair value of its biological assets and could be a reference for companies in preparing financial statements.

\section{RESEARCH METHOD}

This research was conducted in South Kalimantan. The sample areas were Banjarmasin City, Banjarbaru City, Banjar Regency, Tapin Regency and Tanah Laut Regency.

This research was descriptive research by analyzing data obtained fromrespondents on the recognition and measurement of biological assets in the form of plantation crops until presented in the financial statements according to the standard.

The sources of data in this study were: primary data, i.e. data from respondents in the form of answers to distributequestionnaires to the Company's Financial Manager of Palm oil Plantations in South Kalimantan region.

Primary data were collected using list of questions in the form of direct questionnaires from research respondents.

\section{Analysis Technique}

Accounting treatment of biological assets in plantation industry based on Financial Accounting Standards starting from recognition, measurement and presentation in the financial statements. Index or the number of conformity with the Accounting Treatment of Biological Assets Standards.

\section{RESULTS AND DISCUSSION}

\section{Description of Questionnaires Distribution}

The research data obtained by distributing the questionnaires to 10 palm oil companies spread over 2 cities and 3 regencies, Banjarmasin City, Banjarbaru City, Banjar Regency, Tapin Regency, and Tanah Laut Regency. The distribution of the questionnaires can be seen in Table 1 below. 
Table 1 Questionnaires Distribution Details

\begin{tabular}{|c|c|c|}
\hline Company name & City/Regency & Questionnaire \\
\hline 1. PT. Fass Forest Development & Banjarmasin & 1 \\
\hline 2. PT. Citra PuteraKebunAsri & Banjarmasin & 1 \\
\hline 3. PT. BuanaKarya Bhakti & Banjarmasin & 1 \\
\hline 4. PT. KaryaPratamaAgri Sejahtera & Banjarbaru & 1 \\
\hline 5. PT. Jaya MandiriSukses & Banjarbaru & 1 \\
\hline 6. PT. MinamasPlantions & Banjarbaru & 1 \\
\hline 7. PT. Borneo Indo Tani & Banjar & 1 \\
\hline 8. PT. Hasnur Citra Terpadu & Tapin & 1 \\
\hline 9. PT. KharismaInti Usaha & Tapin & 1 \\
\hline 10. PT. Perkebunan Nusantara XIII & Tanah Laut & 1 \\
\hline Total & & $\mathbf{1 0}$ \\
\hline
\end{tabular}

Source: Data reprocessed (2017)

\section{Analysis of Biological Assets Implementation}

Biological assets can be grouped by time period of its biological transformation, namely short-term biological assetsand long-term biological assets, depending on the period of biological transformation possessed by the biological assets or the required time period of the biological assets to be ready for sale. Based on the grouping, the following is the respondents' answers related to the classification of biological assets according to the company, as follows:

Table 2 Classification of Biological Assets

\begin{tabular}{lllc}
\hline \multicolumn{1}{c}{ Biological Assets Description } & Yes & No & \% (percentage) \\
\hline $\begin{array}{l}\text { The company has defined and understood } \\
\text { about biological assets }\end{array}$ & 10 & 0 & 100 \\
\hline $\begin{array}{l}\text { Plantation crops or industrial plantations } \\
\text { forest has already classified into } \\
\text { immature plants and mature plants }\end{array}$ & 10 & 0 & 100 \\
\hline \multicolumn{2}{l}{ The Average Classification of Biological Assets } \\
\hline
\end{tabular}

Source: Data processed, 2017

Table 2 shows that all companies (10 respondents) or $100 \%$, have defined and understood about biological assets. The companies have classified the plantation crops (forest industry plants) into immature plants and mature plants. Immature plants (IP) are new plants (MP) that have grown well in the field and its status is set to have entered the IP period. The IP period starts from the time the seedlings are planted until harvested for the first time, while the mature plants (MP) are plants which $60 \%$ or more of the fruits have matured or the plants have been 31 months old.

The recognition of biological assets is based on that nursery, immature plants (TBM), the mature plants (TM), and the fresh fruit bunches (TBS) at harvest. The sales result of the harvest in the form of TBS which will be sold to buyers in an active market and will be processed at the plant to produce palm oil product $(C P O)$ less cost of sales isrecognized as revenue. Based on the answers of respondents, the recognition of biological 
Table 3 Recognition of Biological Assets

\begin{tabular}{|c|c|c|c|}
\hline Recognition of biological assets & Yes & No & $\begin{array}{c}\% \\
\text { (percentage) }\end{array}$ \\
\hline $\begin{array}{l}\text { The company controls the biological assets as a } \\
\text { result of past events }\end{array}$ & 9 & 1 & 90 \\
\hline $\begin{array}{l}\text { There are future economic benefits associated } \\
\text { with these biological assets }\end{array}$ & 9 & 1 & 90 \\
\hline $\begin{array}{l}\text { The Company recognizes plantation crops as } \\
\text { Immature Plants (IP) which are considered as } \\
\text { plants that have not been able to produce and still } \\
\text { under development. }\end{array}$ & 10 & 10 & 100 \\
\hline $\begin{array}{l}\text { The Company recognizes IP at the acquisition } \\
\text { cost of capitalization of direct costs and indirect } \\
\text { costs related to the development of IP }\end{array}$ & 10 & 10 & 100 \\
\hline $\begin{array}{l}\text { The Company classifies the plantation plants that } \\
\text { are in the productive periods into mature plants } \\
\text { (MP). }\end{array}$ & 10 & 10 & 100 \\
\hline $\begin{array}{l}\text { The Company does Amortization on the mature } \\
\text { plants }\end{array}$ & 10 & 10 & 100 \\
\hline \multicolumn{3}{|c|}{ Average Recognition of Biological Assets } & 96.67 \\
\hline
\end{tabular}

Source: Data processed, 2017

assets according to the company is as indicated in Table 3.

Based on Table 3 as many as nine companies or $90 \%$ stated that the entity controlling the biological assets as a result of past events and possible future economic benefits related to the ownership of biological assets is, but all companies (100\%), have recognized the TBM at acquisition cost which can be measured reliably with fair value. All companies (100\%) classify productive plantation crops into mature plants. Productive plant (bearer plant) is a plant used in the production or supply of agricultural products. To recognize the value of plants thathas already entered the productive plants, the company noted in a journal reclassification.
Productive plants that have produced should be calculated its depreciation. The whole company is doing amortization in plants that are mature plants.

\section{Measurement and Valuation of Biological Assets}

The measurement of biological assets on initial recognition and at each reporting date based on the fair value less cost of sales unless the fair value can not be relied upon. If the fair value is difficult to rely on, the company can use the acquisition cost less accumulated amortization or impairment to measure the assets. The measurement of biological assets according to the company is: 
Table 4 Measurement and Valuation of Biological Assets

\begin{tabular}{|c|c|c|c|}
\hline Measurement and Valuation of biological assets & Yes & No & $\begin{array}{c}\% \\
\text { (percentage) }\end{array}$ \\
\hline $\begin{array}{l}\text { The fair value or the acquisition cost of a } \\
\text { biological asset can be reliably measured }\end{array}$ & 10 & - & 100 \\
\hline $\begin{array}{l}\text { The Company measures the plantation crops fair } \\
\text { value based on spot price, i.e the } \\
\text { price prevailing on the transaction date }\end{array}$ & 9 & 1 & 90 \\
\hline $\begin{array}{l}\text { The Company measures the fair value of plantation } \\
\text { crops based on the current market price of } \\
\text { transactions on biological assets, or market prices } \\
\text { for similar biological assets after adjustment less } \\
\text { the cost to sell at the point of harvest }\end{array}$ & 8 & 2 & 80 \\
\hline $\begin{array}{l}\text { Gains or losses arising from the initial recognition } \\
\text { of biological assets at fair value less costs to sell }\end{array}$ & 7 & 3 & 70 \\
\hline $\begin{array}{l}\text { Gains or losses incurred upon initial recognition of } \\
\text { agricultural products at fair value lesscosts to sell }\end{array}$ & 8 & 2 & 80 \\
\hline Average Measurement of Biologic & ssets & & 84 \\
\hline
\end{tabular}

Source: Data processed, 2017

Based on Table 4, explains that the company uses fair value in valuing biological assets as a percentage of $100 \%$. Biological assets are measured at initial recognition and at the end of reporting at fair value less costs to sell. But it is not easy to measure the fair value of biological assets because the market prices are not available, it can be seen from theaforementioned data that only 8 companies (80\%)measure fair value of plantation crops based on the latest market on biological assets transaction, or market price for similar biological assets.

While the measurement associated with the gain or loss arising on initial recognition of biological assets at fair value less costs to sell. There were 3 companies (30\%) who did not measure the gain or loss on initial recognition of biological assets with fair value while the initial recognition of agricultural products there were 2 companies (20\%) as well. The conditions allegedly occurred because the companies experience the difficulty to determine fair value of biological assets. In such cases, biological assets may be measured at acquisition cost lessaccumulated depreciation and accumulated impairment losses.

\section{Presentation and Disclosure of Biological Assets in Financial Statements}

The presentation of biological assets, in the form of plantation crops, is classified into inventory accounts and long term assets. Long term assets account will accommodate entity's plantation crops that can not be sold because it is still undergoing a process of growth.

Based on the above presentation of biological assets, the presentation of assets according to the company is: 
Table 5 Presentation of Biological Assets

\begin{tabular}{lccc}
\hline $\begin{array}{l}\text { Presentation of Biological Assets } \\
\text { in the Financial Statement }\end{array}$ & Yes & No & $\begin{array}{c}\text { \% } \\
\text { (percentage) }\end{array}$ \\
\hline $\begin{array}{l}\text { The company describes each group of its biological } \\
\text { assets }\end{array}$ & 10 & 100 \\
\hline $\begin{array}{l}\text { The Company classifies biological assets, between } \\
\text { mature and immature assets }\end{array}$ & 10 & 100 \\
\hline $\begin{array}{l}\text { The Company presents gains or losses arising from } \\
\text { fair valuechanges in that period }\end{array}$ & 10 & 100 \\
\hline $\begin{array}{l}\text { The Company describes the significant methods } \\
\text { and assumptions applied in determining the fair } \\
\text { value of each group of agricultural product at the } \\
\text { harvest point and each group of biological assets }\end{array}$ & 9 & 1 \\
\hline $\begin{array}{l}\text { The Company presents fair value at the market } \\
\text { price of agricultural products that are harvested less } \\
\text { the cost of sales in that period. }\end{array}$ & 9 & 1 & 90 \\
\hline \multicolumn{1}{c}{ Average Presentation of Biological Assets } \\
\hline
\end{tabular}

Source: Data processed, 2017

Table 5 describes the presentation of biological assets in the financial statements. The company has already described any biological assets owned and classified it into Mature Plants (MP) and Immature Plants (IP). The company also presents advantages and disadvantages from the changes in fair value with the presentation level of $100 \%$. However, not all companies explain the method and assumption of the fair value implementation of each agricultural product group.

The following information must be disclosed in the notes to financial statements of the entity concerned with gains or losses arising from changes in fair value during that period; a description of each group of its biological assets, methods and significant assumptions applied in determining the fair value of each group of agricultural product.The biological asset disclosures by the company are presented in Table 6.

Based on Table 6 overall the companies have disclosed well the biological assets with a range of disclosure $80-100 \%$ from disclosure items. However, related to the disclosure of the fair value of biological assets, the companies that disclose only 50\% - 60\%. As described previously the problem to measure the fair value of biological assets is the market price is not available, causing difficulty in determining the gain or loss due to the fair value in the form of biological assets and agricultural products $(70 \%)$.

A total of 9 companies (90\%) have revealed the depreciation method for plants that have already produced along with the economic life of the plants and presented the gross amount of accumulated depreciation either at the beginning or at the end of the period. For the loss of the decliningof fair value only 8 companies $(80 \%)$ which have disclosed.

Overall, the companies have applied the Accounting treatment for biological assets based on the applicable accounting standard, although there are some items that are not applied as described above. Below is a summary of Accounting treatment of biological assets in the plantation industry in South Kalimantan by sampling of 10 palm oil companies representing Banjarmasin City, Banjarbaru City, Banjar Regency, Tapin Regency and Tanah Laut Regency. 
Table 6 Disclosure of Biological Assets

\begin{tabular}{llcc}
\hline $\begin{array}{l}\text { Disclosure of Biological Assets } \\
\text { in the Financial Statement }\end{array}$ & Yes & No & $\begin{array}{c}\text { \% } \\
\text { (percentage) }\end{array}$ \\
$\begin{array}{l}\text { The Company has outlined the types of } \\
\text { biological assets }\end{array}$ & 10 & 0 & 100 \\
\hline $\begin{array}{l}\text { The Company discloses the combination of } \\
\text { benefits and losses incurred during the process } \\
\text { at the recognition of biological assets and } \\
\text { agricultural products }\end{array}$ & 7 & 3 & 70 \\
\hline $\begin{array}{l}\text { Fair value changes less the cost to sell the } \\
\text { biological assets }\end{array}$ & 6 & 4 & 60 \\
\hline $\begin{array}{l}\text { Company explains why fair value can not be } \\
\text { measured reliably }\end{array}$ & 5 & 5 & 50 \\
\hline $\begin{array}{l}\text { The Company discloses the depreciation } \\
\text { method used clearly }\end{array}$ & 9 & 1 & 90 \\
\hline $\begin{array}{l}\text { The Company has disclosed the economic age } \\
\text { and depreciation rates used. }\end{array}$ & 9 & 1 & 90 \\
\hline $\begin{array}{l}\text { Gross amount and accumulated depreciation at } \\
\text { the beginning and at the end of the period }\end{array}$ & 8 & 2 & 80 \\
\hline Loss of impairment & 8 & 2 & 80 \\
\hline \multicolumn{1}{c}{ Average Disclosure of Biological Assets } & & 77.5 \\
\hline
\end{tabular}

Source: Data processed, 2017

Table 7 Summary of Accounting Treatment of Biological Assets based on the Research Indicators

\begin{tabular}{lcc}
\hline $\begin{array}{c}\text { Accounting Treatment of } \\
\text { Biological Assets }\end{array}$ & $\begin{array}{c}\text { Number of Items of } \\
\text { Accounting Treatment of } \\
\text { Biological Assets based on } \\
\text { Research Indicators }\end{array}$ & $\begin{array}{c}\text { Average Implementation in } \\
\text { Company } \\
\text { (in\% Percentage) }\end{array}$ \\
\hline Classification & 2 & 100 \\
\hline Recognition & 6 & 96.7 \\
\hline Measurement and Valuation & 6 & 84 \\
\hline Presentation & 5 & 77.5 \\
\hline Disclosure & 8 & 454.2 \\
\hline \multicolumn{1}{c}{ Amount } & & 90.8 \\
\hline Average Asset Accounting Treatment in Company & \\
Financial Statements & in &
\end{tabular}

Based on Table 7 illustrates that on average of $90,8 \%$ of companies have applied the Accounting treatment for biological assets based on research indicators. In terms of classification, the companies have $100 \%$ Journal of Wetlands Environmental Management classified its biological assets well. Recognition, measurement and valuation of biological assets, the companies have applied research indicators in the range of $84 \%-97 \%$. While Presentation and Disclosure of Biological Assets in 
the financial statements, the companies have implemented 77, 5\% - 96\%. From the data, not all companies implementing research indicators, it is more due to fair value of biological assets which is not easily obtained in the active market, so it has an effect on recognition, measurement, valuation, presentation and disclosures in the financial statements of the company.

The plantation company does have specific characteristics. The uniqueness in this industry is the increase in the assets through growth and revenue associated with asset growth or at the time of sale. In Indonesia, Agriculture is arranged by PSAK N0.69 which will be effective on 1 January 2018.

\section{CONCLUSIONS AND RECOMMENDATIONS}

\section{Conclusions}

The following conclusions can be drawn from this research:

(a) Companies have applied the Accounting treatment for biological assets on average of $90.8 \%$ based on research indicators. In terms of classification, the companies have $100 \%$ classified its biological assets well. Recognition, measurement and valuation of biological assets, the compa 99 have applied research indicators in the range of $84 \%$ - 97\%. While presentation and disclosure of biological assets in the financial statements, the companies have implemented $\quad 77.5 \% \quad-\quad 96 \%$ of the indicator disclosure.

(b) The basis for measuring fair value is the cost of the active market of the commodity. If the market price is not reliable, the alternative of fair value determination can be used. (c) The use of fair value in palm oil plantation companies is not easy because there are no supporting instruments related to the active market price of palm oil. As long as the active market price is not available, the determination of fair value for palm oil crops will not be the same. This is due to obtaining fair value using another alternative will involve the assumption of various parties resulting subjectivity in valuing the asset.

(d) Sufficientpresentation and disclosure of biological assets plants in company financial statements will improve the quality of financial reporting information.

(e) Biological Accounting treatment is regulated through PSAK N0.69 Agriculture that will be effective on 1 January, 2018.

\section{Recommendations}

Based on these results, the suggestions are given by the researchers are:

(a) Future studies are expected to get the active market price demanded by IAS 69 Agriculture, in order to the calculation of biological assets acquires assets appraisal certainly.

(b) Subsequent researches are expected to find the company objects that have applied PSAK 69 Agriculture for its biological assets, in order to be the examples or references for other companies that have not used PSAK 69 Agricultural yet.

\section{REFERENCES}

Adita dan Kiswara. 2012. Analisis Penerapan International Accounting Standard (IAS) 41 pada PT. Sampoerna Agro, Tbk. Jurnal Akuntansi. Vol.1, Nomor 2. Fakultas 
Ekonomika dan Bisnis Universitas Diponegoro. Semarang.

Badan Pengawas Pasar Modal (BAPEPAM). 2002. Pedoman Penyajian dan Pengungkapan Laporan Keuangan Emiten atau Perusahaan Publik Industri Perkebunan. Surat Edaran Bapepam.

Brealey, Richard A. 2004. Fundamentals of Corporate Finance. The McGraw-Hill Companies, Inc.

Ikatan Akuntan Indonesia. 2017. Pernyataan Standar Akuntansi Keuangan. Jakarta: Salemba Empat.

International Accounting Standard Committee (IASC). 2009. International Accounting Standard 41 Agriculture.

Martani, Dwi., Sylvia Veronica NPS., Ratna Wardhani., Aria Farahmita, dan Edward Tanujaya. 2015. Akuntansi Keuangan Menengah Berbasis PSAK. Jakarta: Salemba Empat.

Pardamean, Maruli. 2011. Sukses Membuka Kebun Dan Pabrik Kelapa Sawit. Jakarta: Penebar Swadaya.

Safitri, Syamsi.,Fitrizal, dan Lusiana. 2012. Perlakuan Akuntansi Aset Biologis
Hubungannya dengan Kualitas Informasi Keuangan pada PT. Perkebunan Nusantara VI Jambi (Persero). Jurnal.UPI "YPTK". Padang.

Sari, Diana Tiara. 2011.Tinjauan Atas Penilaian Aset Dengan Pendekatan Nilai Wajardan Nilai Historis dalam Penilaian Aset Biologi (Pada Perusahaan Golden Agri - Resource LTD).

Sitomorang, Rani Dame dan Sipatmi. 2014. Praktik Perlakukan Aset Biologis pada Perusahaan Perkebunan (Persero) di Indonesia. Salatiga.

Suwardjono. 2010. Teori Akuntansi Perekayasaan Pelaporan Keuangan. Edisi Ketiga. BPFE. Yogyakarta.

Tyas, Esti Laras Aruming dan Nurul Fachriyah. Evaluasi Penerapan Standar Akuntansi Keuangan dalam Pelaporan Aset Biologis (Studi Kasus Pada Koperasi "M"). Jurnal. Fakultas Ekonomi dan Bisnis Universitas Brawijaya. Malang.

Wirahardja, Roy Iman. 2010. Adopsi IAS 41 dalam Rangkaian Konvergensi IFRS di Indonesia. Ikatan Akuntan Indonesia (IAI). 